\title{
Van earthquakes (23 October 2011 and 9 November 2011) and performance of masonry and adobe structures
}

\author{
D. Güney \\ Division of Structure, Department of Architecture, Faculty of Architecture, Yildiz Technical University, \\ 34469 Istanbul, Turkey \\ Correspondence to: D. Güney (deguney@yildiz.edu.tr)
}

Received: 5 September 2012 - Accepted: 20 October 2012 - Published: 14 November 2012

\begin{abstract}
Earthquakes, which are unavoidable natural phenomena in Turkey, have often produced economic and social disaster. The latest destructive earthquakes happened in Van city. Van, Turkey, earthquakes with $M=7.2$ occurred on 23 October 2011 at 13:41 (local time), whose epicenter was about $16 \mathrm{~km}$ north of Van (Tabanlıvillage) and $M=5.6$ on 9 November 2011 epicentered near the town of Edremit south of Van in eastern Turkey and caused the loss of life and heavy damages. Both earthquakes killed 644 people and 2608 people were injured. Approximately 4000 buildings collapsed or were seriously damaged. The majority of the damaged structures were seismically insufficient, unreinforced masonry and adobe buildings in rural areas. In this paper, site surveys of the damaged masonry and adobe buildings are presented and the reasons for the caused damages are discussed in detail.
\end{abstract}

\section{Introduction}

23 October 2011, Van city in eastern Turkey was hit by a large earthquake at 13:41 (10:41 GMT), on Sunday afternoon of magnitude 7.2. This earthquake can be evaluated as shallow earthquake (about $10 \mathrm{~km}$ depth). The Van earthquake, whose epicenter was about $16 \mathrm{~km}$ north of Van province, between Ercis county (population about 77000 ) and Van city (population about 370000 ), has devastated the area (demolished many buildings with hundreds of people dead and thousands injured under the ruins. The location of epicenter can be seen in Fig. 1. Ercis County ( $90 \mathrm{~km}$ away from Van city) was mainly affected by earthquake. Hundreds of buildings totally collapsed; thousands of them were heavily damaged and 644 people died as shown in Table 1 (604 died in first earthquake, 61 in the center, 66 in villages in the vicinity and 477 in Erciş; 40 people died because of second earthquake). The total economic loss is about 1 billion Turkish Lira (TL) to 4 billion TL (approx. 555 million-2.2 billion USD). This would represent around 17 to $66 \%$ of the provincial GDP (Gross Domestic Product) of Van (AFAD, 2011).

The second (centered in Edremit, Van) earthquake (9 November 2011, $M_{\mathrm{W}}=5.6$ ) caused much more structural damage in Van city center than first earthquake (23 September 2011, $M_{\mathrm{W}}=7.2$ ). The epicenter of the earthquake was near the town Edremit south of Van (as shown in Fig. 1). Lightly or moderately damaged buildings in Van totally collapsed or were heavily damaged. The second earthquake caused collapse or heavy damage in Van city center (40 people killed by earthquake) with thousands of buildings seriously damaged in Van city center.

In the area of Lake Van and further east, tectonics is dominated by the Bitlis suture zone (in eastern Turkey) and Zagros fold and thrust belt (toward Iran). The 23 October 2011 earthquake occurred in a broad region of convergence beyond the eastern extent of Anatolian strike-slip tectonics. The focal mechanism of recent earthquakes is consistent with obliquethrust faulting similar to mapped faults in the region. Given its tectonic history, a major earthquake in Anatolia is by no means an unusual event and other major earthquake events are to be expected in the region as the central block continues to be squeezed westwards and lateral movement occurs along the fault complexes of both North and East Anatolian Fault (as shown in Fig. 2).

Major earthquakes such as this one have occurred in the year 1111 causing major damage and having a magnitude around $6.5-7$. In the year 1646 or 1648, Van was again struck by a $M=6.7$ (magnitude $=6.7$ ) quake killing around 

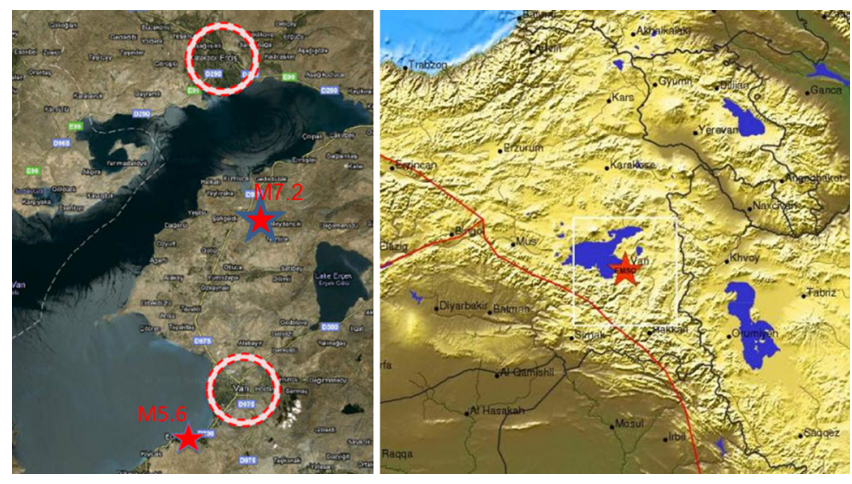

Fig. 1. Location of earthquake epicenter.

Table 1. Human loss and collapsed buildings.

\begin{tabular}{lrrr}
\hline Location & Killed & Injured & $\begin{array}{r}\text { Total Collapsed } \\
\text { Building }\end{array}$ \\
\hline Center, Van & 101 & 1150 & 10 \\
Erciş, Van & 477 & 1058 & 100 \\
Villages & 66 & 400 & 2197 \\
Total & 644 & 2608 & 2307 \\
\hline
\end{tabular}

2000 people. In 1881 , a $M=6.3$ earthquake near Van killed 95 people. Again, in 1941, a $M=5.9$ earthquake affected Ercis and Van killing between 190 and 430 people. 19451946 as well as 1972 brought again damages and casualties, bearing earthquakes to the Van province. In 1976, the Muradiye, Van, earthquake struck the border region with a $M=7$, killing around 3840 people and causing around 51000 people to become homeless. In recent past (according to historical records from 1900), there were 10 earthquakes that happened with $M=5-6,3$ earthquakes with $M=6-7$, and 2 earthquakes with $M=7-7.5$. The damages and human loss in eastern Turkey can be seen Fig. 3. The energy released by earthquake is calculated as $2.09 \times 10^{15} \mathrm{~J}$. This energy is 33.2 times more than Hiroshima atomic bomb explosion energy (Özkaymak et al., 2003).

This earthquake caused extensive damages not only to the reinforced concrete structures but also unreinforced masonry buildings. Many of the damaged building types were stone, brick or briquette masonry or adobe with low construction and material quality. In this paper, the results of the site surveys are presented and the lessons learned from the earthquake and structural damages are discussed.

\section{Seismological and geological properties of the region}

The Van Lake Basin is located in the East Anatolian Plateau, which resulted from the collision between the Eurasian an Arabian Plates in Late Miocene (Şengör and Kidd, 1979; Şengör and Yılmaz, 1983). The basin, formed in Late Pliocene (Şaroğlu and Yılmaz, 1986), is underlined by a

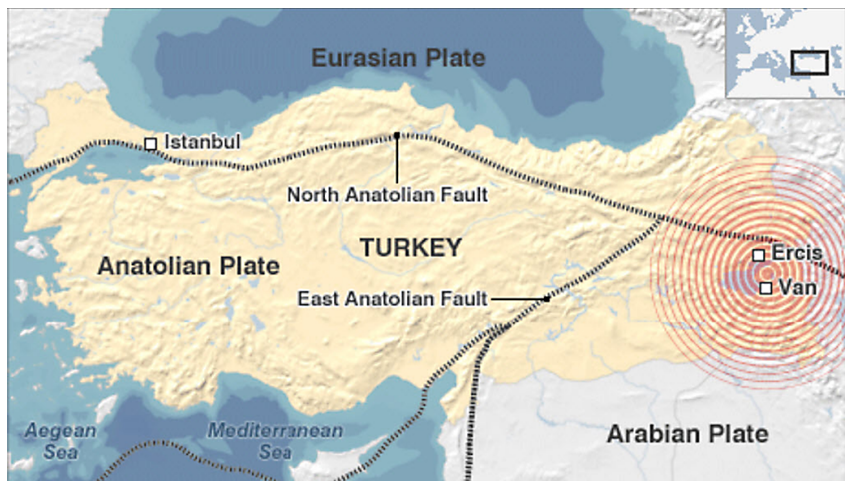

Fig. 2. Van and Erciş are located in eastern Turkey by Lake Van (BBC, 2011).

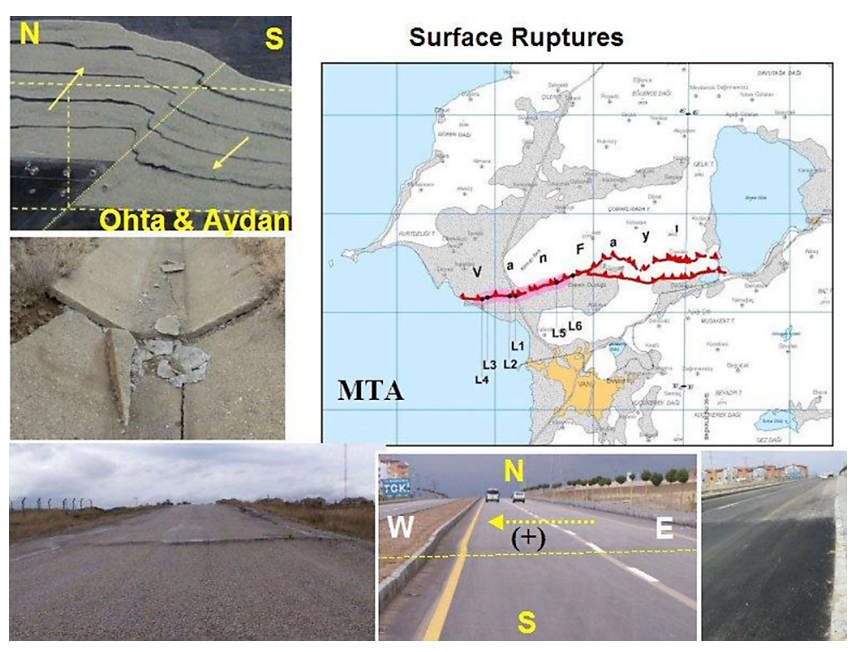

Fig. 3. Views of surface rupture along the fault trace (Emre et al., 2011).

basement consisting of Bitlis metamorphic rocks, Upper Cretaceous ophiolites and Tertiary-aged marine sediments. In the region surrounding Van Lake, different rock units and alluvial deposits formed between Paleozoic and Holocene are observed. Van Lake region includes metamorphic rocks belonging to the Bitlis massive to the south, and volcanic and volcano-clastic rocks to the west and north that originated from the old volcanoes called Nemrut, Süphan and Tendürek. Van Lake, situated at $1.648 \mathrm{~m}$ a.s.l. in the eastern Taurus Mountains of southeast Turkey, is the fourth largest terminal lake in the world (a body of water with streams discharging into it without any outflows).

The main shock is believed to have been on a WSW-ENE reverse fault with north-dipping fault plane; the fault was not identified on the active fault map of Turkey. The November quake (second earthquake) is believed to have occurred on a strike-slip fault also previously unidentified. The estimated average relative displacement of the fault is more than $2 \mathrm{~m}$ according to the empirical relation proposed by 


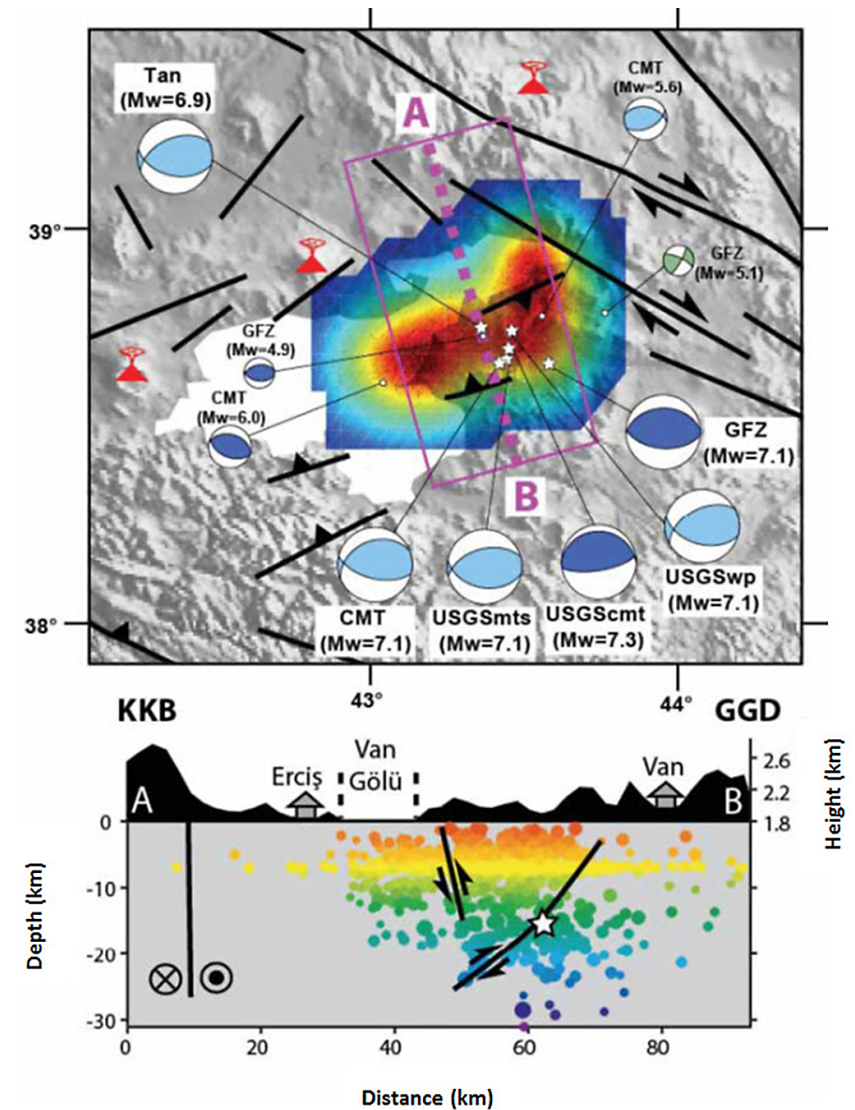

Fig. 4. Seismotectonic distribution of Van Lake and surroundings (METU, 2011a).

Aydan (2007); there was no clear fault scarp on the ground surface as shown in Fig. 3. The earthquake originated at a depth ranging between $5-19 \mathrm{~km}$ depending upon the institutes, and it resulted from the movement of a $50-\mathrm{km}$-long and 20-km-wide thrust fault trending about E-W direction from Erçek Lake into Van Lake. The major energy release occurred within $20 \mathrm{~s}$, although the total duration of the rupture was about $50 \mathrm{~s}$.

The region around Van has a complex seismic setting due to the interaction between the Arabian and the Eurasian tectonic plates. The area has east-west thrust fault zones, as well as northwest-southeast right-lateral and northeast-southwest left-lateral translational fault zones as shown in Fig. 4.

The seismic intensity map shows us aftershocks have been concentrated around the edge of the north-east edge of Van Lake at zone of NE-SW direction.

The largest earthquake recorded in the region during the last century was the $1976 M=7.2$ Çaldıran (Muradiye) earthquake (Gulkan et al., 1978), although the $1945 M=5.8$ Çatak, $1972 M=5.2$ Van, and the $1977 M=5.1$ Ercis earthquakes were significant as well. The loss count for historic earthquakes in eastern Turkey is shown in Fig. 5.
Earthquakes

1976 Muradiye

1966 Varto

2011 Van-Ercis

1975 Lice

1992 Erzincan

1971 Bingol

1983 Narman-Horasan

2003 Bingol

0.778

0.687

0.553

0.386

0.345

0.271

0.238

0.122

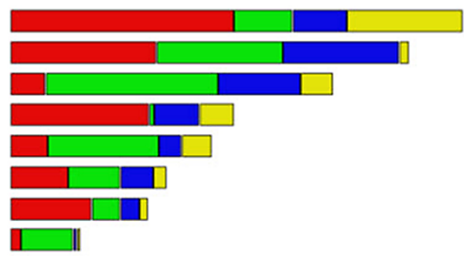

Deaths

Injured

Fig. 5. Loss count for historic earthquakes in eastern Turkey.

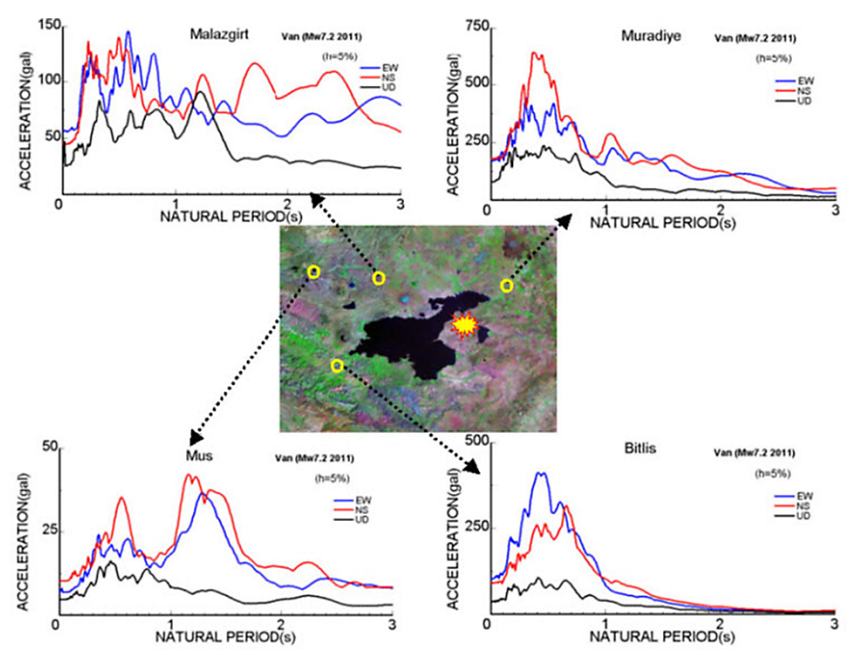

Fig. 6. Acceleration response spectra at selected strong motion stations.

The acceleration responses of these strong motion stations together with those of Malazgirt and Muş strong motion stations are shown in Fig. 6. Maximum spectral acceleration is observed for a natural period of $0.4 \mathrm{~s}$ for Muradiye $(42 \mathrm{~km})$ record. In view of natural periods common to reinforced concrete (RC) structures in Turkey, the acceleration response of 66 and 86story RC buildings should have been much higher. This result can explain why $6-8$ story RC buildings collapsed or were heavily damaged during this earthquake.

The strong ground motion station in Van did not record the ground shaking from the October main shock due to a malfunction. The closest station that recorded ground motion was the Muradiye station $\left(38.99011^{\circ} \mathrm{N}, 43.76302^{\circ} \mathrm{E}\right)$, approximately $40 \mathrm{~km} \mathrm{NNE}$ from the epicenter. Acceleration response spectra are shown in Fig. 7. It is believed that Ercis had ground shaking more strongly than that in Muradiye. The station in Van recorded the November ground motion with peak accelerations (unprocessed) as $148 \mathrm{~cm} / \mathrm{s}^{2}(\mathrm{~N}-\mathrm{W})$, $246 \mathrm{~cm} / \mathrm{s}^{2}(\mathrm{E}-\mathrm{W})$, and $151 \mathrm{~cm} / \mathrm{s}^{2}(\mathrm{U}-\mathrm{D})$. 

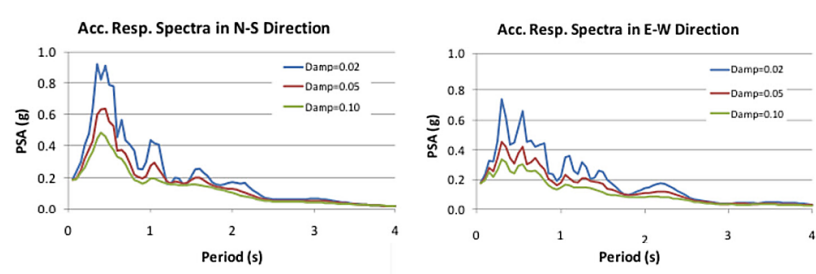

Fig. 7. Response spectra for the N-S and E-W records for the Muradiye station motion (unprocessed) recorded during the main shock (METU, 2011b).

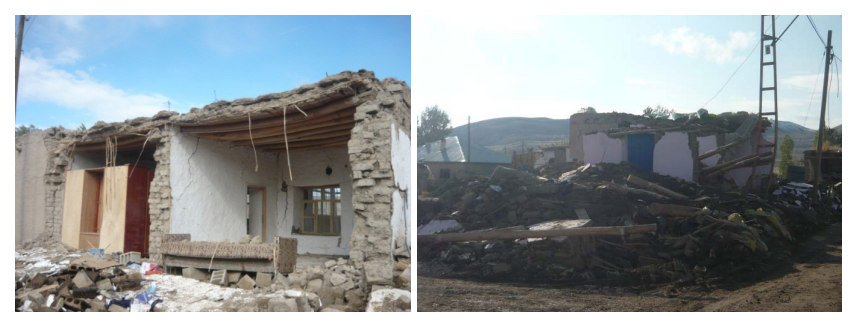

Fig. 8. Heavy roof with wooden beams of damaged and collapsed adobe building (Güveçli village, Van).

\section{Seismic performance of masonry and adobe buildings}

Adobe and masonry buildings are very common in rural areas of Turkey because of easy workmanship and cheap construction cost. However, these buildings are always seriously affected by earthquakes as observed before (Cetinkaya, 2011). The masonry buildings in the region hit by the earthquakes were constructed by mud bricks, stones/pebbles taken from the river banks, soft natural stone blocks and lime hollow/solid blocks. Adobe buildings were constructed from adobe bricks made by formation of mud with wooden bracings. These materials have been used as structural material; however, they do not fulfill code or any provision (Turkish seismic codes MPW, 1975, 1998, 2007) requirements. Generally existing buildings in the region were one or two stories with a very heavy roof over a wooden infrastructure (Fig. 8). This type of heavy roofing significantly increases the mass of the building that leads to an increase in seismic forces during earthquakes. Turkish structural design code defines such masonry buildings as non-earthquake resistant buildings.

Even though the magnitude and spectral acceleration values of the earthquakes were not so large compared with codedefined spectra, many masonry and adobe buildings completely collapsed or were heavily damaged, caused by abovementioned construction applications and poor construction material. The area hit by earthquake was surveyed, and detailed studies were carried out on the damaged buildings to analyze the reasons of the weak performance of the masonry and adobe buildings. The reasons are discussed in detail based on investigations of damaged buildings in the region.

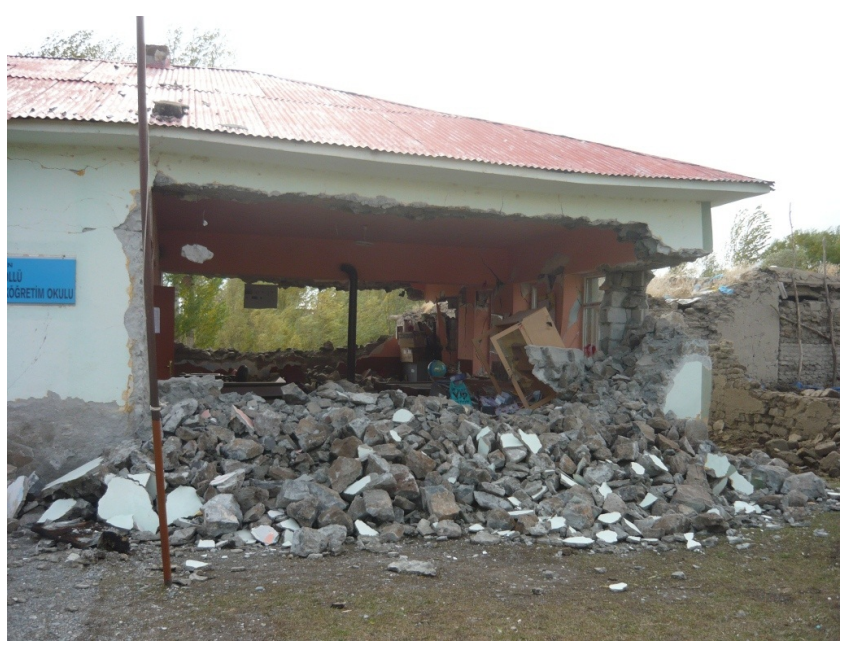

Fig. 9. Lack of interlocking between wall leaves in school building (Göllü village, Van).

One of the most important reasons was the use of improper construction material. Rubble stone, briquette and soft stone blocks were the masonry materials widely used in the damaged or collapsed buildings. Dried mud blocks and wooden beams were the most common material for adobe buildings. Soft stone blocks used in masonry have low compression strength and ductility values. The rubble stone blocks taken from the river beds and banks used as masonry material do not have a proper shape for the use in the masonry walls. These blocks have smooth and round surfaces with irregular dimension and improper granulometry. It is nearly impossible to construct an overlapping masonry wall section using this type of construction material without cutting them into proper dimensions and shapes. Adobe blocks (dried mud) also have low compression and tensile strength. Wooden elements used in adobe vertically and horizontally do not have desired material and mechanical properties. That is why many adobe buildings totally collapsed or were heavily damaged in the region because of earthquake. In addition to this, poor workmanship is another source of damage of these types of structures.

The masonry walls built by stone were constructed as inner and outer leaves. The total thickness of them was generally about $50 \mathrm{~cm}$. The unsupported length of the outer leaf of the masonry wall was increased two times because of lack of interlocking elements which is necessary to connect the inner and outer leaves to each other and transfer lateral load. But its effective thickness being reduced to half of the wall thickness results in a dramatic increase in the out-of-plane collapse risk since it is directly proportional to slenderness ratio of the wall. Figure 9 shows this kind of damage.

The insufficient and inappropriate connection of the walls was another common reason observed for the damages. It was observed that the connections in the collapsed or 


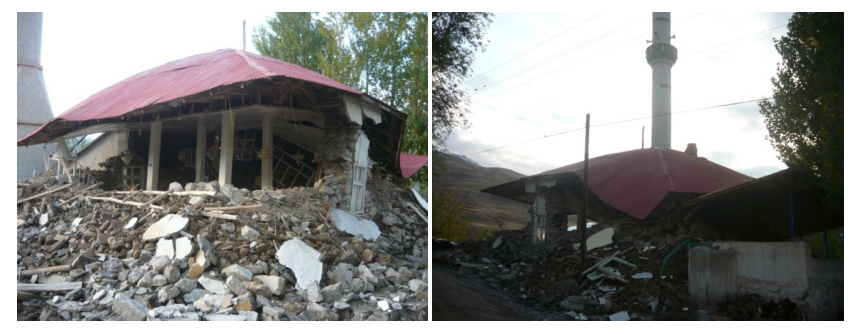

Fig. 10. No connection to partition walls of mosque (Dağönü village, Van).

damaged buildings had not been properly constructed to transfer horizontal forces resulting from earthquake. Figure 10 shows this type of wall collapse. In a building, the exterior walls should have proper connection with the partition walls. Nevertheless, the exterior walls of the most of the damaged buildings were found to be not connected to partition walls. Thus, the free span of the exterior wall was so large that it could not resist masonry wall out-of-plane failure.

One of the most common reasons for partial or total collapse was incorrect location of the openings in the walls. Building codes for seismic design limit the distance between the two openings and the distance between the opening and corner of the walls (MPW, 1975, 1998, 2007), because the masonry and adobe walls are the only structural elements that bear lateral loads of the masonry buildings. According to Turkish Building Code (2007), the minimum distance between two openings should be at least $1 \mathrm{~m}$ and the minimum distance between an opening and a building corner should be $1.5 \mathrm{~m}$.

Another common reason for damages in the buildings hit by earthquake is the inadequate distance between two windows. Irregular shape of the masonry units shown in Fig. 10 is also as vital as the inadequate wall length. In addition, the damage level in that wall could be higher if the bonding beams at mid-height and at the top of the walls were not damaged. The damage shown in Fig. 11 is an example for the damages caused by the inadequate distance between the opening and the building corner.

Although the bond beams on top of the walls are very crucial for seismic resistance, damaged masonry and adobe buildings did not have this type of beams on top of the walls. In addition, a heavy roof (filled with earth) with inadequate in-plane stiffness does not provide a rigid diaphragm effect, which is also one of the important reasons for this kind of failure (see Fig. 12). Because walls, bond beams and roofs were not properly connected to each other to transfer the seismic loads to each other, they performed beyond desired level since these infill walls behaved as free-standing walls.

In this region agriculture and livestock are very important for local economy. However, many animal sheds experienced serious damage in the area. Many of them collapsed or were

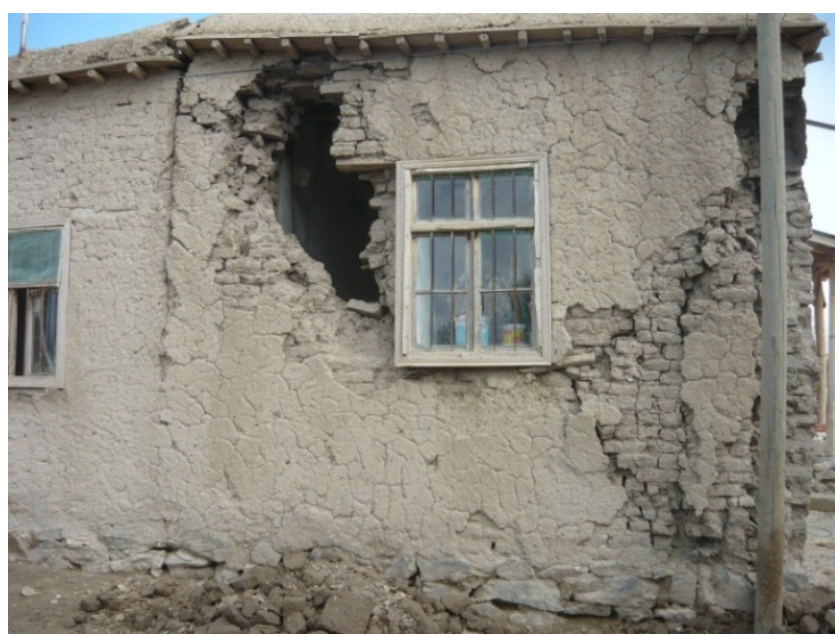

Fig. 11. Wall opening close to the building corner (Güveçli village, Van).

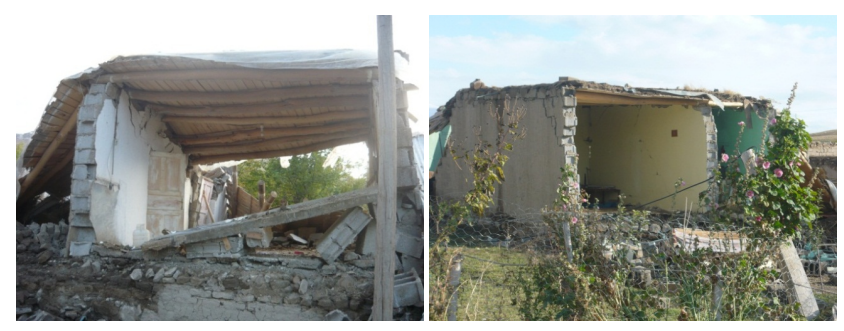

Fig. 12. Out-of-plane failure due to long span (Güveçli village, Van).

seriously damaged. These sheds were also built as adobe and brick masonry. Compared with adobe and masonry residential houses, material and workmanship quality of these sheds were very low. Animal sheds are also other types of structures many of which collapsed or were seriously damaged. Compared with residential houses, these sheds were poorly constructed. They had so much span length due to lack of partitioning wall. Because of this, the collapse of long, unsupported, outer walls occurred throughout off-plane. As seen in most of the figures, the use of improper mortar material or poor quality of bonding mortar is also one of the main reasons for the damages. Mud was even used as mortar to connect wall elements to each other due to economic reasons.

\section{Conclusions}

The rural areas with one- or two-story unreinforced masonry or adobe structures are the areas where the earthquake damaged the buildings most. The lack of interlocking element between external and internal leaves of the wall sections and the lack of connection between crossing walls are the most important reasons why the masonry and adobe structures failed. 
Both of them resulted in an increase in the possibility of outof-plane failure since their formation increases net length of the walls or leaves. Another common reason for failures was the lack of bond beams at the top of wall. For example, a heavy roof was put on the walls directly, which increased the seismic demands and resulted in failures. Improper placement of openings was also another important reason for the commonly seen damages. Concentrated serious cracks were observed around or between the doors and windows. In addition, poor performance of building also resulted from poor quality of masonry units and adobe bricks during the earthquake, because, in rural areas of Turkey, building codes were not strictly enforced as much as they were enforced in urban areas.

Because of similar practices to those in the developing countries in the world, the risks of significant damage in the masonry and adobe buildings, especially in rural areas of Turkey, are very high in future earthquakes. Being highly seismic area, Turkey experiences serious seismic activities, which result in serious damages in both urban and rural areas every two years ( $M=5$ or larger). However, the percentage of life losses and damages is higher in rural areas. Most of the buildings that were damaged or collapsed are one- or twostory masonry or adobe structures. Therefore, to decrease the seismic damage risk in the masonry and adobe structures, it is very urgent to take necessary measures. These measures should be economic, practical and applicable.

Acknowledgements. Author thanks to the Yildiz Technical University for its support during site surveys.

Edited by: M. E. Contadakis

Reviewed by: two anonymous referees

\section{References}

Aydan, Ö.: Inference of seismic characteristics of possible earthquakes and liquefaction and landslide risks from active faults, The 6th National Conference on Earthquake Engineering of Turkey, Istanbul, 1, 563-574, 2007 (in Turkish).

British Broadcasting Corporation (BBC): Turkey earthquake: Survivors outdoors on freezing night, available at: http://www.bbc. co.uk/news/world-europe-15437014 (last access: 28 September 2011), 2011.

Cetinkaya, N.: 2010 Karakocan-Elazig earthquake and masonry structures, Nat. Hazards Earth Syst. Sci., 11, 11-16, doi:10.5194/nhess-11-11-2011, 2011.

Disaster and Emergency Management Directorate (AFAD): Press Bulletin on the 23 October and 9 November 2011 Van earthquakes, available at: http://www.deprem.gov.tr/sarbis/Shared/ WebBelge.aspx?param=_103, last access: 24 November 2011 (in Turkish).

Emre, Ö., Duman, T. Y., Özalp, S., and Elmac1, H.: 23 Ekim 2011 Van depremi saha gözlemleri ve kaynak faya ilişkin ön değerlendirmeler, MTA Jeoloji Etütleri Dairesi Raporu, Ankara, 2011.

Gülkan, P., Gürpinar A., Çelebi, M., Arpat, E., and Gençoğlu, S.: Engineering Report on the Muradiye-Caldiran, Turkey, Earthquake of 24 November 1976, National Academcy of Sciences, Washington DC, 1978.

METU, Eq. Eng. Research Center: "The 23 October 2011 Mw 7.2 Van earthquake seismic and structural damage field observations (in Turkish)," Report METU/EERC, available at: http://www. eerc.metu.edu.tr/sites/default/files/Van_ODTUDMAMRapor.pdf (last access: 20 November 2011), 2011a.

METU, Eq. Eng. Research Center: Processed Mainshock Accelerometric Recordings of the 23 October 2011 Van Earthquake, Report METU/EERC, available at: http://www.eerc. metu.edu.tr/sites/default/files/Report_VanEQ2011.pdf (last access: 20 November 2011), 2011 b.

Özkaymak, Ç., Sağlam, A., and Köse, O.: Van Gölü doğusu aktif tektonik özellikleri, Aktif Tektonik Araştırma Grubu 7. Toplantıs1- ATAG VII, Van, Turkey, 2003.

Şaroğlu, F. and Yılmaz, Y.: Doğu Anadolu'da neotektonik dönemdeki jeolojik evrim ve havza modelleri, Maden Tetkik ve Arama Dergisi, 107, 73-94, 1986 (in Turkish).

Şengör, A. M. C. and Kidd, W. S. F.: Post-collisional Tectonics of the Turkish Iranian Plateau and a Comparison with Tibet, Tectonophysics, 55, 361-376, 1979.

Şengör, A. M. C. and Yılmaz, Y.: Türkiye'de Tetis'in Evrimi: Levha Tektoniği Açısından bir Yaklaşım, Türkiye Jeoloji Kurumu Yerbilimleri Özel Dizisi, no. 1, İstanbul, 1983.

Turkish Ministry of Public Works and Settlement (MPW): Regulations for structures to be built in disaster areas, Ankara, 1975, 1998, 2007 (in Turkish).

Turkish Earthquake Resistant Code, Turkish Ministry of Construction and Housing, Ankara, 2007. 